\title{
NOTE
}

\section{Measurement of oxygen metabolism in open-top aquatic mesocosms: application to a coral reef community}

\author{
Nicolas Leclercq, Jean-Pierre Gattuso*, Jean Jaubert** \\ Observatoire Océanologique Européen, Centre Scientifique de Monaco, Avenue Saint-Martin, MC-98000 Monaco, Principality of Monaco
}

\begin{abstract}
A new experimental and analytical protocol enabling the measurement of the metabolism of aquatic communities in open-top mesocosms is described. It involves estimation of air-water gas exchange and use of a polynomial regression to estimate metabolic parameters from measurements of dissolved oxygen concentration. Sample data is provided for a coral reef community. Its major advantage compared to the standard respirometry technique is that the community is not subject to great variations of physical and chemical parameters such as dissolved oxygen concentration or $\mathrm{pH}$ during the experiment. Changes in the concentration of dissolved oxygen were measured over $24 \mathrm{~h}$ periods and used to derive community gross photosynthesis $\left(P_{\mathrm{g}}\right)$ and respiration (R). Experiments performed on the same community with 2 differents light intensities ( 360 and $250 \mu \mathrm{mol} \mathrm{m}^{-2} \mathrm{~s}^{-1}$ ) provided consistent estimates of $P_{\mathrm{g}}\left(208 \pm 50\right.$ and $73 \pm 20 \mathrm{mmol} \mathrm{O}_{2} \mathrm{~m}^{-2}$ $\left.\mathrm{d}^{-1}\right)$ and $R\left(-219 \pm 55\right.$ and $\left.-79 \pm 29 \mathrm{mmol} \mathrm{O} \mathrm{m}^{-2} \mathrm{~d}^{-1}\right)$. The airwater oxygen transfer velocities, $K_{\mathrm{O}_{2}}$ varied between $34 \pm 5$ and $84 \pm 12 \mathrm{~cm} \mathrm{~h}^{-1}$ This approach provided estimates of community metabolism that are not significantly different from those obtained using the standard respirometry technique.
\end{abstract}

KEY WORDS: Primary production - Respiration - Mesocosms · Coral reef community Aquatic ecosystem

Mesocosms and microcosms are artificially constructed ecosystems maintained in containers isolated from natural ecosystems (Beyers \& Odum 1993). They have been used in ecological studies for many years (Woodruff 1912, Gause 1934) and enable the running of small-size ecosystems for days, months or years (Adey 1983, Jaubert et al. 1995, Luckett et al. 1996). They are tools for experiments that could not be carried out on natural systems, such as effect of changes in environmental parameters (e.g. light, temperature,

- Present address: Observatoire Océanologique, ESA 7076 CNRS, BP 28, F-06234 Villefranche-sur-mer Cedex, France

-Addressee for correspondence.

E-mail: jaubert@naxos.unice.fr salinity, $\mathrm{pCO}_{2}$ and water motion) on community structure and function (Parsons 1981, Oviatt 1994). The use of mesocosms in experimental ecology has been criticized by several authors (Heath 1980, Kinsey 1985, Hendrey 1992, Carpenter 1996, Nijs et al. 1996), who pointed out limitations such as variability between mesocosms, low species diversity, low environmental variability and small-scale approach. Mesocosms are, nevertheless, powerful tools to investigate system behavior when field experiments cannot be performed or when the system under investigation is too complex (Oviatt 1994, Lawton 1996).

Community metabolism of an aquatic mesocosm can be measured using various techniques, depending on the type of mesocosm under investigation. Flowthrough mesocosms are open systems continously supplied with 'new' water, the exchange rate being adjusted to be able to measure a significant change of selected parameters. Community metabolism of such systems can be investigated using an adaptation of the flow respirometry technique (Marsh \& Smith 1978) by measuring differences in the water chemistry between the inflowing and the outflowing seawater (Henderson \& Smith 1980, Henderson 1982, Griffith et al. 1987). Mesocosms which are closed in terms of seawater supply can be open or closed to the atmosphere. Open-top mesocosms have seldom been used to investigate the community metabolism of aquatic systems (Jaubert et al. 1995, Langdon \& Sweeney 1995). It is indeed difficult to estimate the gas exchange across the air-water interface but this problem can be avoided by sealing the mesocosm and using it as a respirometer (Kinsey 1978, McCloskey et al. 1978). This method is, however, difficult to implement because it requires that the container be completely filled, in order to avoid the presence of air, and that regular partial flushing be carried out in order to avoid great variation in, for example, dissolved oxygen and carbon dioxide. 
Coral reefs comprise several communities, making this ecosystem one of the most diverse, complex and productive ecosystems on earth. Field studies of community metabolism began in the late 1940s (Sargent \& Austin 1949, Odum 1956) and considerable information is now available on community productivity and calcification of coral reef flats (Smith 1995, Gattuso et al. 1998). Additionally, Smith \& Buddemeier (1992) suggested that community metabolic parameters could be used as a tool to investigate the response of coral reefs to environmental stress. However, relatively few studies have used mesocosms for investigating coral reef metabolism (Henderson \& Smith 1980, Henderson 1982, Adey 1983, Griffith et al. 1987. Atkinson et al. 1995, Jaubert et al. 1995, Luckett et al. 1996).

The aim of the present study was to develop a new experimental and analytical protocol enabling the measurement of the community metabolism of an open-top aquatic mesocosm. This method, which estimates the air-sea $\mathrm{O}_{2}$ transfer velocity $\left(K_{\mathrm{O}_{2}}\right)$, was applied to a coral reef open-top mesocosm. Comparison of the derived metabolic parameters with those obtained both in the field and in the laboratory demonstrated the usefulness of the open-top mesocosm in community metabolism measurements and experimental ecology.

Materials and methods. The reef community studied was settled in an $0.58 \times 0.58 \times 0.58 \mathrm{~m}$ aquarium. The substratum (surface area $=0.34 \mathrm{~m}^{2}$ ) was a live sand system: a carbonate sand layer (5 $\mathrm{cm}$ thick) separated the main seawater reservoir (90 l) from a small volume (15 I) of confined water (Jaubert 1989). The aquarium contained Mediterranean seawater (salinity $=38.3$ ) passed through a sand filter and heated to $27 \pm 0.1^{\circ} \mathrm{C}$ using a temperature controller (EliWell-PC 902T). The water was renewed between experiments at a rate of $5 \% \mathrm{~h}^{-1}$. Light was provided by a $400 \mathrm{~W} /$ Daylight metal halide lamp (Philips HPI-T) that could be moved up and down in order to control irradiance as required. The lamp ran on a $12: 12 \mathrm{~h}$ photoperiod. Irradiance (= photosynthetic photon flux density) was measured using a $4 \pi$ quantum sensor (LI-193SA, LI-COR Inc.). Water motion was ensured by a $1000 \mathrm{l} \mathrm{h}^{-1}$ centrifugal pump (Aquarium System, Maxijet 1000) and gas exchange was promoted by air pumps (Réna Alizé and Réna 301) fitted to 1 or 2 air stones. The glass windows of the tank were cleaned daily to prevent algal growth.

The reef community used for the experiments comprised coral sand and calcareous live rocks on which small (5 to $15 \mathrm{~cm}$ in diameter) scleractinian coral colonies (2 Acropora spp., 1 Favia sp.) and several sea anemones (Aiptasia sp.) were growing. The microfauna usually associated with a coral reef community include small crustaceans, polychaetes and gastropods (Stomatela sp.). The hard substratum covered approximately one-third $\left(0.11 \mathrm{~m}^{2}\right)$ of the total surface area. Most organisms of the community were collected in the Red Sea and were introduced in the mesocosm 3 yr prior to the present study.

Water temperature was measured $\left( \pm 0.1^{\circ} \mathrm{C}\right)$ and logged every minute using a temperature recorder (Seamon, Hugrùn). The concentration of dissolved oxygen was measured using an amperopolarographic electrode (Ponselle, oxythermometric model OXY TS). The electrode was calibrated daily, before and after each experiment. One liter of air-saturated sea water stirred (magnetic stirrer) and aerated (air pump, Réna Alizé, running with 1 air stone) in a beaker, was allowed to cool slowly ( 30 to $40 \mathrm{~min}$ ) from 26 to $20^{\circ} \mathrm{C}$. The variation of water temperature resulted in a variation of oxygen content. The electrode was calibrated against the theoretical values of the oxygen content, which were determined with an empirical relationship using the temperature, the salinity and the atmospheric pressure (Wanninkhof 1992). All the data were averaged and logged every minute with a data-logger (LI-1000, LI-COR Inc.).

Three experiments were carried out on the same reef community under different irradiance and water regimes (see Table 1 ). The first experiment was performed under a high photon flux density $\left(360 \mu \mathrm{mol} \mathrm{m} \mathrm{m}^{-2}\right.$ $\mathrm{s}^{-1}$ ) and an oxygen transfer velocity $\left(K_{\mathrm{O}_{2}}\right)$ varying from 20 to $87 \mathrm{~cm} \mathrm{~h}^{-1}$. The second one was set under the same photon flux density but $K_{\mathrm{O}_{2}}$ was set to 2 ranges by controlling the water regime. The third experiment was performed under a lower photon flux density $(250$ $\mu \mathrm{mol} \mathrm{m}^{-2} \mathrm{~s}^{-1}$ ) and 2 fixed water regime surfaces.

The mesocosm was always kept open to the atmosphere except during measurements of community metabolism using the respirometry technique. It was then filled with heated Mediterranean seawater ( $\mathrm{S}=$ $38.3 ; 27^{\circ} \mathrm{C}$ ), kept at $360 \mu \mathrm{mol} \mathrm{m} \mathrm{m}^{-2} \mathrm{~s}^{-1}$ and sealed using a glass cover and a neoprene gasket. Oxygen concentration was measured as described above. Net community production (NCP) was measured several hours after the light went on and several hours after the light went off. Night respiration $(R)$ and gross primary production $\left(P_{\xi}\right)$ were compared using Student's t-tests.

Data are reported as mean \pm standard deviation of the mean.

The model. The dissolved oxygen concentration in the mesocosm depends on the metabolism of the aquatic organisms (photosynthesis and respiration) as well as on the air-sea gas exchange. It was assumed that the water body present underneath the sandwater interface acted as interstitial water and was part of the community. Air-sea gas exchange is determined by Fick's law: 


$$
\Phi_{\mathrm{d}}=\frac{K_{\mathrm{O}_{2}} \cdot\left(C_{\mathrm{sat}}-C_{t}\right)}{6}
$$

where $\Phi_{\mathrm{d}}$ : air-sea oxygen flux ( $\left.\mu \mathrm{mol} \mathrm{O}_{2} \mathrm{~m}^{-2} \mathrm{~min}^{-1}\right) ; K_{\mathrm{O}_{2}}$ : oxygen transfer velocity $\left(\mathrm{cm} \mathrm{h}^{-1}\right), C_{\text {sat }}$ and $C_{i}$ : concentration of dissolved oxygen of air-saturated seawater and of the mesocosm seawater at a given time ( $\mu \mathrm{mol}$ $\left.\mathrm{I}^{-1}\right)_{i}$ and 6 is a constant required to express $\Phi_{\mathrm{d}}$ in $\mu \mathrm{mol}$ $\mathrm{O}_{2} \mathrm{~m}^{-2} \mathrm{~min}^{-1}$.

$C_{\text {sat }}$ varies as a function of temperature, salinity and atmospheric pressure (Wanninkhof 1992). $K_{\mathrm{O}_{2}}$ is often estimated in the field from wind speed data using an empirical relationship (Liss \& Merlivat 1986, Wanninkhof 1992). This method cannot be used in a mesocosm since there is no wind, although $\mathrm{O}_{2}$ is definitely exchanged at the air-water interface. Langdon \& Sweeney (1995) proposed a method that they successfully used in the Biosphere II ocean mesocosm. The oxygen concentration is raised to $250 \mu \mathrm{mol} \mathrm{l^{-1 }}$ by bubbling the seawater with oxygen-rich air. The oxygen then decreases for $6 \mathrm{~d}$ before reaching a new steady state, close to the concentration of air-saturated seawater. The decrease of oxygen concentration is used to estimate $K_{\mathrm{O}_{2}}$. A simulation carried out with Stella software (version II, High Performance Systems) showed that this method can only be used with very large mesocosms where the water column is large (several $\mathrm{m}$ ). We provide below an alternate method, based on a polynomial regression technique, to estimate $K_{\mathrm{O}_{2}}$.

The $\mathrm{O}_{2}$ concentration in our reef mesocosm was constant at night, increased steeply when light was switched on, reached a new steady state during the light period and decreased to reach the nighttime steady state concentration when the lamp was switched off (Fig. 1A). A polynomial regression is used to explain these changes in $\mathrm{O}_{2}$ concentration. It is based on the following theoretical model: at each time $t$, the variation of dissolved oxygen concentration (Fig. 1B) in the coral reef mesocosm is a function of the air-sea gas exchange, the respiration rate $\left(R, \mathrm{O}_{2}\right.$ consumption; $R$ is considered to be negative throughout the paper) and the rate of gross primary production $\left(P_{\mathrm{g}}\right.$, gross $\mathrm{O}_{2}$ production). $N C P\left(P_{\mathrm{g}}+R\right)$ is measured during the daylight period. $P_{\mathrm{q}}$ was estimated by adding $R$ to $N C P$, assuming that it is constant throughout the $24 \mathrm{~h}$ experi- ments. This assumption is often used in studies of reef community metabolism (e.g. Odum 1956, Kinsey 1978) although there is no experimental evidence to support it. The model can be described by the following equation:

$$
\frac{\Delta \mathrm{O}_{2}}{\Delta t}=\Phi_{\mathrm{d}}+R+\left\{\begin{array}{l}
P_{\mathrm{g}}(\text { light period }) \\
0 \text { (dark period })
\end{array}+e\right.
$$

where $\frac{\Delta \mathrm{O}_{3}}{\Delta t}$ : dependent variable, variation of dissolved oxygen concentration as a function of time ( $\mu \mathrm{mol} \mathrm{O}_{2}$ $\left.\mathrm{m}^{-2} \mathrm{~min}^{-1}\right) ; \Phi_{\mathrm{d}}$ : air-sea oxygen flux $\left(\mu \mathrm{mol} \mathrm{O}_{2} \mathrm{~m}^{-2} \mathrm{~min}^{-1}\right)$; $P_{g}$ : rate of gross primary production $\left(\mu \mathrm{mol} \mathrm{O}_{2} \mathrm{~m}^{-2}\right.$ $\left.\mathrm{min}^{-1}\right) ; R$ : rate of respiration $\left(\mu \mathrm{mol} \mathrm{O}_{2} \mathrm{~m}^{-2} \mathrm{~min}^{-1}\right)$; and e: residuals.

Eq. (2) can be expanded as follows:

$$
\frac{\Delta \mathrm{O}_{2}}{\Delta t}=\frac{K_{\mathrm{O}_{2}}\left(C_{\text {sat }}-C_{t}\right)}{6}+\left\{\begin{array}{c}
P_{\mathrm{g}} \text { (daylight) } \\
0 \text { (night) }
\end{array}+R+e\right.
$$

For the sake of convenience,

$$
F=\frac{K_{\mathrm{O}_{2}} \cdot\left(C_{\mathrm{sat}}-C_{t}\right)}{6} \text { and } \Delta=\frac{\Delta \mathrm{O}_{2}}{\Delta t}
$$

The model presented in Eq. (3) can be expressed as a matrix equation:
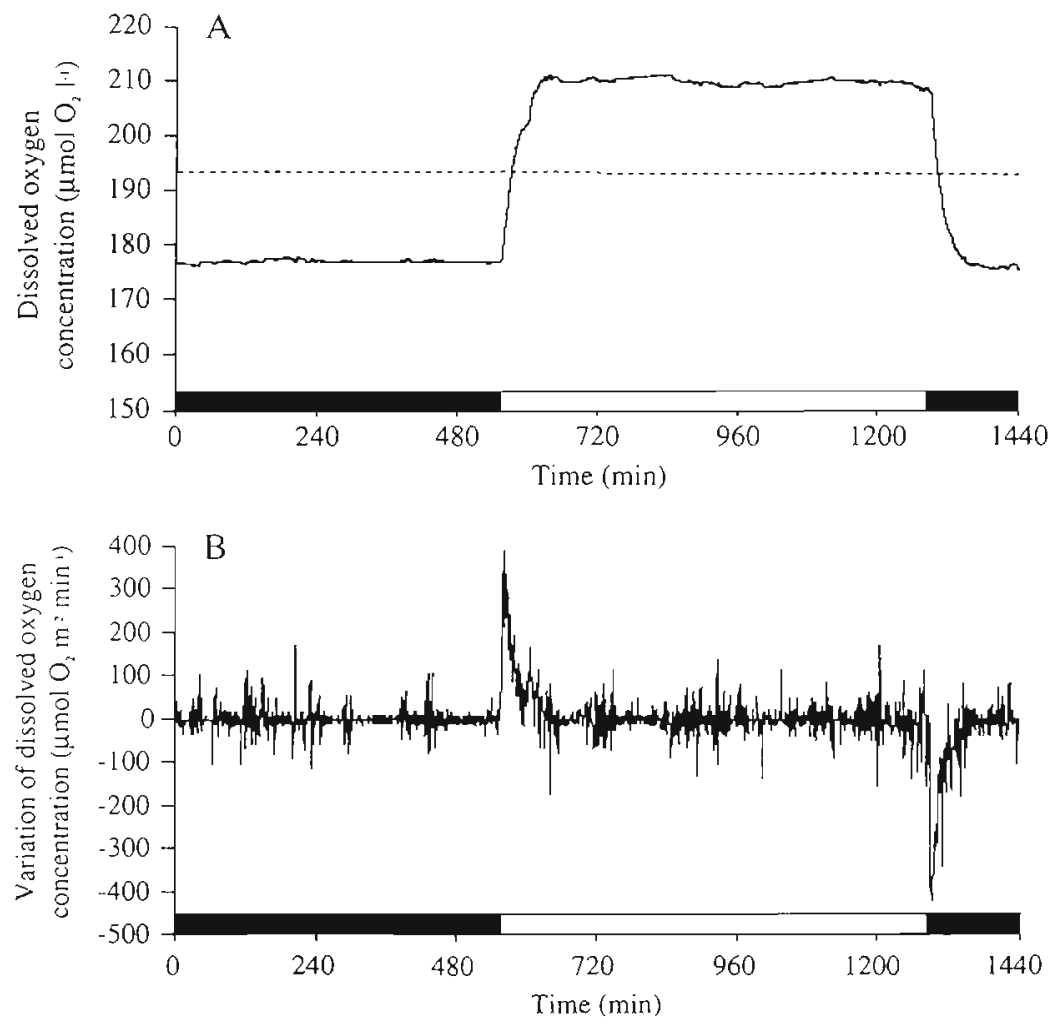

Fig. 1. (A) Concentration of dissolved oxygen in the coral reef mesocosm during a $24 \mathrm{~h}$ experiment. The dashed line shows the dissolved oxygen concentration of air-saturated seawater. (B) Changes in dissolved oxygen. These data represent the best example of the trend observed 


$$
\begin{aligned}
{\left[\begin{array}{c}
\delta_{1} \\
\delta_{2} \\
\cdot \\
\cdot \\
\delta_{n}
\end{array}\right]=\left[\begin{array}{c}
f_{1} \\
f_{2} \\
\cdot \\
\cdot \\
f_{n}
\end{array}\right] \cdot K_{\mathrm{O}_{2}}+\left[\begin{array}{c}
1 \\
1 \\
\cdot \\
0 \\
1
\end{array}\right] \cdot P_{\mathrm{g}}+R+\left[\begin{array}{c}
e_{1} \\
e_{2} \\
\cdot \\
e_{n}
\end{array}\right] } \\
\Delta=F \cdot K_{\mathrm{O}_{2}}+X p_{\mathrm{g}} \cdot P_{\mathrm{g}}+R+e
\end{aligned}
$$

with $n$ varying from 1 to 1440 and $X p_{g}=1$ during the light period and $X p_{\mathrm{g}}=0$ in darkness.

$P_{\mathrm{g}}$ and $\Phi_{\mathrm{d}}$ can be split into $X p_{\mathrm{g}} \cdot P_{\mathrm{g}}$ and $F \cdot K_{\mathrm{O}_{2}} \cdot K_{\mathrm{O}_{2}}$ and $P_{\mathrm{g}}$ are the partial regression coefficients (i.e. constants). $X p_{g}$ and $F$ are the independent variables and are known since the photoperiod, $C_{\text {sat }}$ and $C_{t}$ are known. So, the polynomial regression leads to the estimation of $K_{\mathrm{O}_{2}}, P_{\mathrm{g}}$ and $R$.

Polynomial regressions are carried out on the daily records of dissolved oxygen variation. The following conditions for the use of polynomial regression have been checked: normality of the residuals, or at least symmetry of their distribution; homoscedasticity and no correlation between residuals and predicted values (Zar 1984). This estimation of the oxygen transfer velocity and metabolic parameters was carried out by fitting Eq. (4) to the variation of dissolved oxygen using JMP 3.1 (SAS Institute Inc.).

Results and discussion. $K_{O_{2}}$, the oxygen transfer velocity: The oxygen transfer velocity ranged from 20 to $87 \mathrm{~cm} \mathrm{~h}^{-1}$, depending on the water motion (Table 1). These values are within the range of the oxygen transfer velocities described in the literature for wind tunnel experiments (Liss \& Merlivat 1986, Wanninkhof 1992) and in situ determinations (Frankignoulle et al. 1996). They correspond to the 'Rough Surface Regime' conditions provided in the field by a wind speed of 5 to $13 \mathrm{~m} \mathrm{~s}^{-1}$ (Liss \& Merlivat 1986). We did not attempt to reach a maximum oxygen transfer velocity but our results suggest that it could be possible to simulate, using additional pumps, air stones or even a wave-making device, any kind of surface regime.

Community metabolism: The estimates of the metabolic parameters were not significantly different over the range of water motion (and $K_{\mathrm{O}_{2}}$ ) used (Student's $t$ tests, $p>0.1$ ) (Fig. 2A,B); they were therefore averaged for each light level. Results of the comparison between respirometric measurements and the method presented here (Table 1, Fig. 3) allowed us to conclude that both methods provide the same estimations for the community metabolic parameters (Student's t-tests, $\mathrm{p}>$ 0.2 ). Those results emphasize the validity of the new method we set up for the measurements of the community metabolism and $K_{\mathrm{O}_{2}}$.

The ranges of $P_{\mathrm{g}}$ and $R$ measured during the experiments were, respectively, 33 to $300 \mathrm{rnmol} \mathrm{O}_{2} \mathrm{~m}^{-2} \mathrm{~d}^{-1}$ and -50 to $-366 \mathrm{mmol} \mathrm{O}_{2} \mathrm{~m}^{-2} \mathrm{~d}^{-1}$. The average daily metabolic parameters measured during each experiment are shown in Table $1 . P_{\mathrm{g}}$ was higher during the 2 experiments carried out under the high irradiance (360 $\left.\mu \mathrm{mol} \mathrm{m} \mathrm{m}^{-2} \mathrm{~s}^{-1} ; 208 \pm 50 \mathrm{mmol} \mathrm{O} \mathrm{m}^{-2} \mathrm{~d}^{-1}, \mathrm{~N}=22\right)$ than under low irradiance $\left(250 \mu \mathrm{mol} \mathrm{m} \mathrm{m}^{-2} \mathrm{~s}^{-1} ; 73 \pm\right.$ $\left.20 \mathrm{mmol} \mathrm{O}_{2} \mathrm{~m}^{-2} \mathrm{~d}^{-1}, N=13\right), R$ was also higher during the first 2 experiments $(-219 \pm 55$ vs $-79 \pm 29 \mathrm{mmol}$ $\mathrm{O}_{2} \mathrm{~m}^{-2} \mathrm{~d}^{-1}$ ). These metabolic performances compare well with those obtained for shallow lagoons (Kinsey \& Domm 1974, Kinsey 1979, Atkinson \& Grigg 1984), for sandy areas (Kinsey 1977, 1979) and for a coral patch (Gattuso et al. 1996). Thus, we conclude that the functional aspect of the community under investigation matches its structure and composition: a community composed of a sandy area with less than $50 \%$ of the hard substratum covered by autotrophic organisms (zooxanthellate scleractinian corals, sea anemones and algae).

The daily $P_{\mathrm{g}} / R$ ratio displayed very little change under different light regimes. The ratios obtained at 360 and $250 \mu \mathrm{mol}$ photons $\mathrm{m}^{-2} \mathrm{~s}^{-1}(0.96 \pm 0.11, \mathrm{~N}=22$ vs $0.97 \pm 0.14, N=13$ ) did not differ significantly (Stu-

Table 1 Oxygen transfer velocities $\left(K_{O_{2}}\right)$ and community gross primary production $\left(P_{\mathrm{g}}\right)$ and respiration $(R)$ estimated using the open-top and the respirometric approaches. The respirometric and open-top methods were compared using data collected within

\begin{tabular}{|c|c|c|c|c|}
\hline & $\begin{array}{c}\text { Irradiance } \\
\left(\mu \mathrm{mol} \mathrm{m}^{-2} \mathrm{~s}^{-1}\right)\end{array}$ & $\begin{array}{c}K_{\mathrm{O} 2} \\
\left(\mathrm{~cm} \mathrm{~h}^{-1}\right)\end{array}$ & $\left(\mathrm{mmol} \mathrm{O} \mathrm{O}_{2} \mathrm{~m}^{-2} \mathrm{~d}^{-1}\right)$ & $\left(\mathrm{mmol} \mathrm{O}_{2} \mathrm{~m}^{-2} \mathrm{~d}^{-1}\right)$ \\
\hline \multicolumn{5}{|l|}{ Open-top } \\
\hline Expt no. 1 & 360 & Between 20 and 87 & $217 \pm 54(16)$ & $-227 \pm 58(16)$ \\
\hline Expt no. 2 & 360 & $\begin{array}{l}34 \pm 5 \quad(4) \\
84 \pm 12(2)\end{array}$ & $184 \pm 27(6)$ & $-196 \pm 43(6)$ \\
\hline Expt no. 3 & 250 & $\begin{array}{l}48 \pm 10(7) \\
75 \pm 16(6)\end{array}$ & $73 \pm 20(13)$ & $-79 \pm 29(13)$ \\
\hline $\begin{array}{l}\text { Respirometry } \\
\text { vs }\end{array}$ & 360 & - & $276 \pm 28(4)$ & $-209 \pm 17(3)$ \\
\hline Open-top & & Between 27 and 87 & $241 \pm 53(9)$ & $-252 \pm 56(9)$ \\
\hline
\end{tabular}
one month. Mean $\pm \mathrm{SD}$ values are given, the sample size is shown in parentheses 

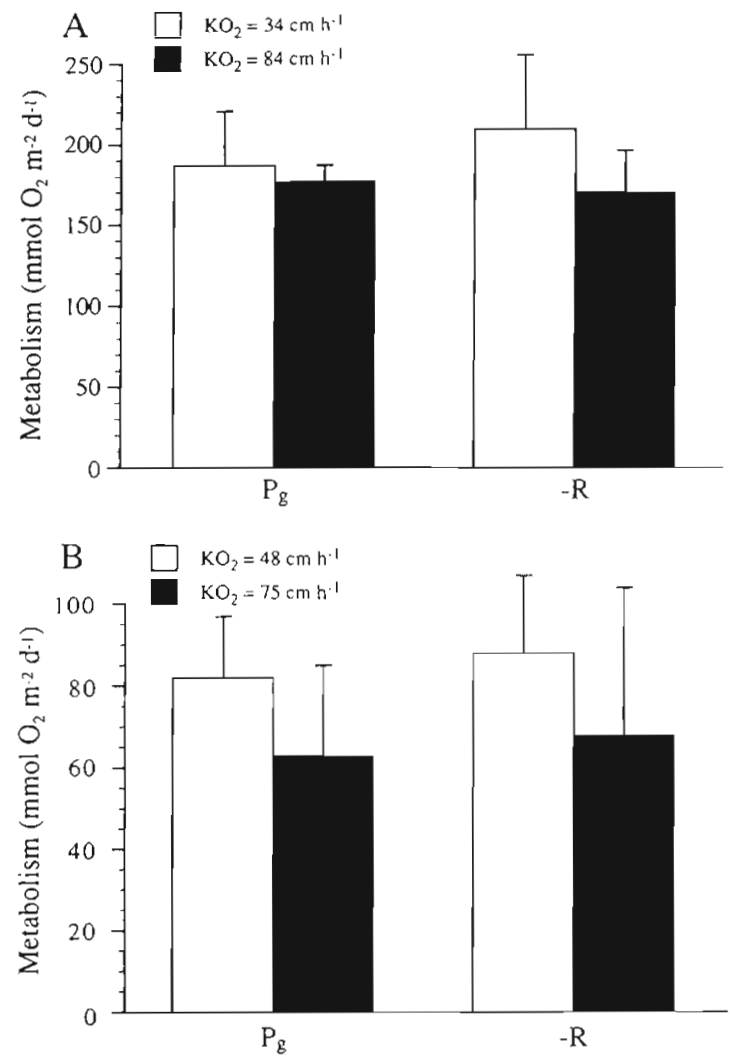

Fig. 2. Estimates of the community daily metabolism $\left(P_{g}\right.$ and $R$ ) using 2 differents oxygen transfer velocities $\left(K_{\mathrm{O}_{2}}\right)$ during the second $(A)$ and the third $(B)$ experiments

dent's $t$-test, $\mathrm{p}>0.8)$. They were therefore averaged and the overall $P_{g} / R$ ratio $(0.96 \pm 0.12, \mathrm{~N}=35)$ is significantly different from 1 (Student's t-test, $\mathrm{p}=0.03$ ). This result is in agreement with the one obtained in another reef mesocosm $\left(P_{\mathrm{g}} / R=0.91\right.$, Jaubert et al. 1995). Community gross primary production and respiration are usually closely balanced in coral reef communities, with $P_{\mathrm{g}} / R$ close to 1 (Kinsey 1983, Kinsey 1985 , Gattuso et al. 1998). The ratio found in the present work is within the range of values reported for natural communities, and the community in the mesocosm exhibits a slightly heterotrophic metabolism. The daily net community productions (daily $N C P$ ) calculated at 360 and $250 \mu \mathrm{mol}$ photons $\mathrm{m}^{-2} \mathrm{~s}^{-1}$ $\left(-11 \pm 25 \mathrm{mmol} \mathrm{O}_{2} \mathrm{~m}^{-2} \mathrm{~d}^{-1}, \mathrm{~N}=22 \mathrm{vs}-5 \pm 11 \mathrm{mmol} \mathrm{O}\right.$ $\mathrm{m}^{-2} \mathrm{~d}^{-1}, \mathrm{~N}=13$ ) were not different for the 2 light intensities (Student's t-test, $\mathrm{p}>0.46$ ) and the overall daily $N C P\left(-9 \pm 21 \mathrm{mmol} \mathrm{O}_{2} \mathrm{~m}^{-2} \mathrm{~d}^{-1}, \mathrm{~N}=35\right)$ is significantly different from zero (Student's $t$-test, $p=0.009$ ). This daily NCP differs from the one found by Griffith et al. (1987) for a microcosm (56 mmol O $\left.\mathrm{m}^{-2} \mathrm{~d}^{-1}\right)$ and indicates that photosynthetically fixed carbon cannot supply the daily heterotrophic needs of the whole community. An external source of organic carbon is

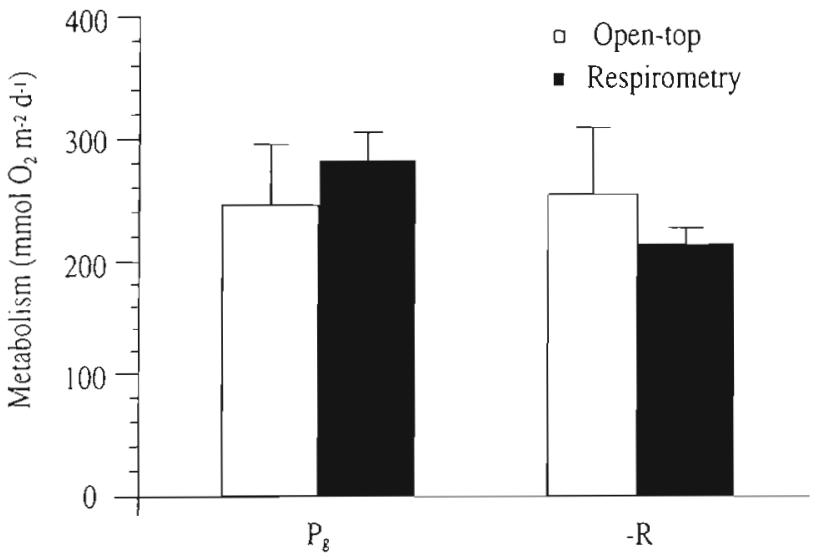

Fig. 3. Estimates of the reef community daily metabolism $\left(P_{\mathrm{g}}\right.$ and $R$ ) using the respirometry method (mean values $\pm \mathrm{SD}$ on 4 experiments for $P_{\mathrm{g}}$ and 3 experiments for $R$ ) and the polynomial regression method (mean values \pm SD on 18 experiments for each parameter)

therefore required. It is likely supplied by the seawater renewal that occurs between experiments.

Conclusion. The method described in the present paper uses a polynomial regression and was set up to study metabolic performance of aquatic ecosystems enclosed in open-top mesocosms. It takes into account the air-water oxygen exchanges by estimating the gas transfer velocity and provides estimates of primary production parameters $P_{\mathrm{g}}$ and $R$ by measuring the variation of dissolved oxygen concentration. This method has been successfully applied to a coral reef mesocosm. The metabolic performance was not significantly different from that determined using a standard respirometric approach and was within the range of those measured in the field. These results demonstrate that some natural communities can be mimicked, in terms of metabolism, in open-top mesocosms. Thus, we assume that this model coral reef community behaves as an analog for a natural reef system and is a potentially useful tool to perform experiments on the effect of environmental factors on coral reef metabolic parameters

Acknowledgements. Thanks are due to M. Marchioretti and $F$. Priouzeau for setting up the mesocosm and providing preliminary results, and to A. Sciandra for providing valuable comments on the experiments as well as on a draft of the paper

\section{LITERATURE CITED}

Adey WH (1983) The microcosm: a new tool for reef research Coral Reefs 1:193-201

Atkinson MJ, Carison B, Crow GL (1995) Coral growth in high-nutrient, low-pH seawater: a case study of corals cultured at the Waikiki Aquarium, Honolulu, Hawaii. Coral Reefs 14:215-223

Atkinson MJ, Grigg RW (1984) Model of a coral reef ecosys- 
tem. II. Gross and net benthic primary production at French Frigate schoals, Hawaii. Coral Reefs 3:13-22

Beyers RJ, Odum HT (1993) Ecological microcosms. SpringerVerlag. New York

Carpenter SR (1996) Microcosm experiments have limited relevance for community and ecosystem ecology. Ecology 77: $677-680$

Frankignoulle $M$, Gattuso JP, Biondo $R$, Bourge $I_{1}$ CopinMontégut G, Pichon M (1996) Carbon fluxes in coral reefs. II. Eulerian study of inorganic carbon dynamics and measurements of air-sea $\mathrm{CO}_{2}$ exchanges. Mar Ecol Prog Ser 145:123-132

Gattuso JP, Pichon M. Jaubert J, Marchioretti M, Frankignoulle $M$ (1996) Primary production, calcification and airsea $\mathrm{CO}_{2}$ fluxes in coral reefs: organism, ecosystem and global scales. Bull Inst Océanogr. Monaco 14:39-46

Gattuso JP, Frankignoulle M, Wollast R (1998) Carbon and carbonate metabolism in coastal aquatic ecosystems Annu Rev Ecol Syst 29:405-433

Gause GF (1934) The struggle for existence. Williams and Wikins, Baltimore, MD

Griffith PC, Cubit JD. Adey WH, Norris JN (1987) Computerautomated flow respirometry: metabolism measurements on a Caribbean reef and in a microcosm. Limnol Oceanogr $32: 442-451$

Heath RT (1980) Are microcosms useful for ecosystem analysis? In: Giesy JP (ed) Microcosm in ecological research. DOE Symposium, series 52-Technical Information Center. US Department of Energy, Washington, DC. p 333-347

Henderson RS (1982) In situ and microcosm studies of diel metabolism of reef flat communities. Proc 4 th Int Coral Reef Symp 1:679-686

Henderson RS, Smith SV (1980) Semitropical marine microcosms: facility design and an elevated-nutrient-effects experiment. In: Giesy JP (ed) Microcosm in ecological research. DOE Symposium, series 52 - Technical Information Center US Department of Energy, Washington, DC, p 869-910

Hendrey GR (1992) Global greenhouse studies: need for a new approach to ecosystem manipulation. In: Hendrey GR (ed) FACE: free-air $\mathrm{CO}_{2}$ enrichment for plant research in the field. CRC Press, Boca Raton

Jaubert $J$ (1989) An integrated nitrifying-denitrifying biological system capable of purifying sea water in a closed circuit aquarium. Bull Inst Océanogr Monaco 5 (spécial): $101-106$

Jaubert J, Marchioretti M, Priouzeau F (1995) Carbon and calcium budget in a semi-closed coral mesocosm. In: Prescott JH, Wilkins L, Barrett C (eds) Prog 3rd Int Aquarium Congr (1993, Boston). New England Aquarium, Boston, MA, p 289-296

Kinsey DW (1977) Seasonality and zonation in coral reef productivity and calcification. Proc 3rd Int Coral Reef Symp, Miami 2:383-388

Kinsey DW (1978) Productivity and calcification estimates using slack-water periods and field enclosures. In: Stoddart DR, Johannes RE (eds) Coral reefs: research methods. Monographs on oceanographic methodology, No. 5. UNESCO, Paris

Kinsey DW (1979) Carbon turnover and accumulation

Editorial responsibility: Otto Kinne (Editor),

Oldendorf/Luhe, Germany by coral reefs. PhD dissertation, University of Hawaii, Honolulu

Kinsey DW (1983) Standards of performance in coral reef primary production and carbon turnover. In: Barnes DJ (ed) Persperctives on coral reefs. Australian Institute of Marine Science, Townsville, p 209-218

Kinsey DW (1985) Metabolism, calcification and carbon production I: systems level studies. Proc 5th Int Coral Reef Congr, Tahiti 4:505-526

Kinsey DW, Domm A (1974) Effects of fertilization on coral reef environment-primary production studies. Proc 2nd Int Coral Reef Symp 1:49-66

Langdon C. Sweeney C (1995) The diel cycle of oxygen in the biosphere II ocean: July-September, 1995. LamontDoherty Earth Observatory/Biosphere II Technical Report

Lawton JH (1996) The ecotron facility at Silwood Park: the value of 'Big Bottle' experiments. Ecology 77:665-669

Liss PS, Merlivat L (1986) Air-sea gas exchange: introduction and synthesis. The role of air-sea exchange in geochemical cycling. D Reidel Publishing Company, Dordrecht, p $113-127$

Luckett C. Adey WH, Morrissey J, Spoon DM (1996) Coral reef mesocosms and microcosms-successes, problems, and the future of laboratory models. Ecol Eng 6:57-72

McCloskey LR, Wethey DS, Porter JW (1978) Measurements and interpretation of photosynthesis and respiration in reef corals. In: Stoddart DR, Johannes RE (eds) Coral reefs: research methods. Monographs on oceanographic methodology, No. 5. UNESCO, Paris

Marsh JA, Smith SV (1978) Productivity measurements of coral reefs in flowing water. In: Stoddart DR, Johannes RE (eds) Coral reefs: research methods. Monographs on oceanographic methodology, No. 5. UNESCO, Paris

Nijs I, Kockelberg F, Blum H, Hendrey G, Impens I (1996) Free-air temperature increase (FATI): a new tool to study global warming effects on plants in the field. Plant Cell Environ 19:495-502

Odum HT (1956) Primary production in flowing waters. Limnol Oceanogr 1:102-117

Oviatt CA (1994) Biological considerations in marine enclosure experiments: challenges and revelations. Oceanography $7: 45-51$

Parsons TR (1981) The use of controlled experimental ecosystems: a review. J Oceanogr Soc Jpn 37:294-298

Sargent MC, Austin TS (1949) Organic productivity of an atoll. Trans A.m Geophys Union 30:245-249

Smith SV (1995) Reflections on the measurements and significance of carbon metabolism on coral reefs. In: Kansas Geological Survey Open-File Report 95-56a. Informal communication of SCOR working group 104. Kansas Geological Survey, Lawrence, KS

Smith SV, Buddemeier RW (1.992) Global change and coral reef ecosystems. Annu Rev Ecol Syst 23:89-118

Wanninkhof R (1992) Relationship between wind speed and gas exchange over the ocean. J Geochem Res 97: $7373-7382$

Woodruff LL (1912) Observatıons on the origin and sequence of the protozoan fauna of Hay infusions. J Exp Zool 12: $205-264$

Zar JH (1984) Biostatistical analysis. 2nd edn. Prentice-Hall Inc, Englewood Cliffs, NJ

Submitted: June 13, 1998; Accepted: October 22, 1998

Proofs received from author(s): February 5, 1999 